\title{
Status and Causes of Chinese Migrant Workers' Crimes
}

\author{
Dejun Zhang $^{1}$ \\ ${ }^{1}$ Law School, University of Jinan, Jinan, China \\ Correspondence: Dejun Zhang, Law School, University of Jinan, Jinan 250022, Shandong, China. E-mail: \\ dejun002@163.com
}

Received: January 26, 2014 Accepted: March 18, 2014 Online Published: April 29, 2014

doi:10.5539/ass.v10n9p62

URL: http://dx.doi.org/10.5539/ass.v10n9p62

\begin{abstract}
In this paper, by means of investigation and analysis of criminal situation and basic characteristics of crimes committed by Chinese migrant workers, we try to reveal the social and individual causes of Chinese migrant workers' crimes as follows: the differences between urban and rural areas demonstrated by the social system defects; oppressive management and rights discrimination; abnormality of personality to the path of crime shaped by their very miserable fate which were caused by social discrimination. At last we attempt to, by using the related sociological and psychological theories, give interpretation of the reasons why migrant workers commit crimes.
\end{abstract}

Keywords: Chinese migrant worker, crime, rural traditional culture, social discrimination, causes

\section{Introduction}

Generally speaking, Chinese migrant workers refer to the workers providing labor for factories and construction sites and for the long term goals of transforming China from a rural-based economy to an urban-based one. As the product of unique urban-rural dual system in China, they are a special group of Chinese society arising in a special period. The migrant workers came from rural areas, but are employed to be engaged in non-agricultural occupations, which their incomes are mainly from, while they are still agricultural registered permanent residents. In 2011, China's total migrant workers reached 252.78 million, an increase of more 10.55 million people, up $4.4 \%$ over the previous year; workers migrated with the families were about 32.79 million, an increase of more 2.08 million, up $6.8 \%$ over the previous year.

With ever-growing migrant workers, crimes committed by them have been the increasing concern, and become a very serious problem that affects social stability. Thus it will have positive impacts on the migrant workers themselves and the stability of the society to pay close attention on and try to solve their crime problems. Based on related statistics of the judicial authorities and prison administration sections in Shandong Province, combining with interviews and field observations, we tried to conduct a preliminary analysis of the status and causes of the migrant workers' crime.

This paper mainly studies three closely related problems: criminal situation of Chinese migrant workers; basic characteristics of crime; causes of migrant workers' crimes. Investigation of migrant workers' criminal situation makes people understand the severity of their crimes and draws the government' attention. Analysis of the characteristics of migrant workers' crimes is to provide direct support for revealing the causes. The research methods used are as follows: empirical analysis - collection and reference of data on migrant workers' crimes in recent years; systematic research - comprehensive analysis from the characteristics of crimes to the underlying causes; theoretical analysis - interpretation of the related problems based on sociological and psychological theories.

\section{Analysis of Crime Status of Migrant Workers}

Crime is the result of interaction between perpetrator's physical condition and social environment. So is the crime committed by migrant workers. Since China's reform and opening up, a large number of migrant workers sprang up by the joint actions of rural economic reform and urbanization. Migrant workers are in a transitional phase in transitional China with the deepening of the market economy system construction. Migrant workers crime is no longer in a decentralized, irregular state under the dual transformation, but showing features of mass participation and regularity. So we can see that the crime of migrant workers in China has evolved from individual behaviors as group behaviors. 
Migrant workers' crime is becoming increasingly serious social problem. According to the collective information of crime investigated, migrant workers' crimes accounted for about $10 \%$ of all crimes around 2002, and there was an annual increase of 3-5\%, until recent years to about $40 \%$, even more than $50 \%$ in some areas. In a word, the proportion of migrant workers' crime increased on a yearly basis. According to the statistics from National People's Court criminal judgments, migrant workers criminals accounted for $11.9 \%$ in all criminals in 2002 , however, up to $42.9 \%$ in 2009 . In addition, data show that the migrant workers' crime rates were under $10 \%$ before 21 st Century, generally at $5 \%$ or so. There is a clear upward trend after 2000 . It is thus clear that there is a parallel increase in the number of migrant workers as well as the number of their crimes, and with a continuation of that trend in the current state. This trend is shown from the following table based on the statistics of a region in Shandong in the last five years. Notably, $90 \%$ of criminals were under the age of $26.80 \%$ of migrant workers criminals were a new generation, who were born in rural areas after 1980s, and left unattended in their childhood. Nearly $60 \%$ of these crimes committed by migrant workers floated into cities blindly.

Table 1.

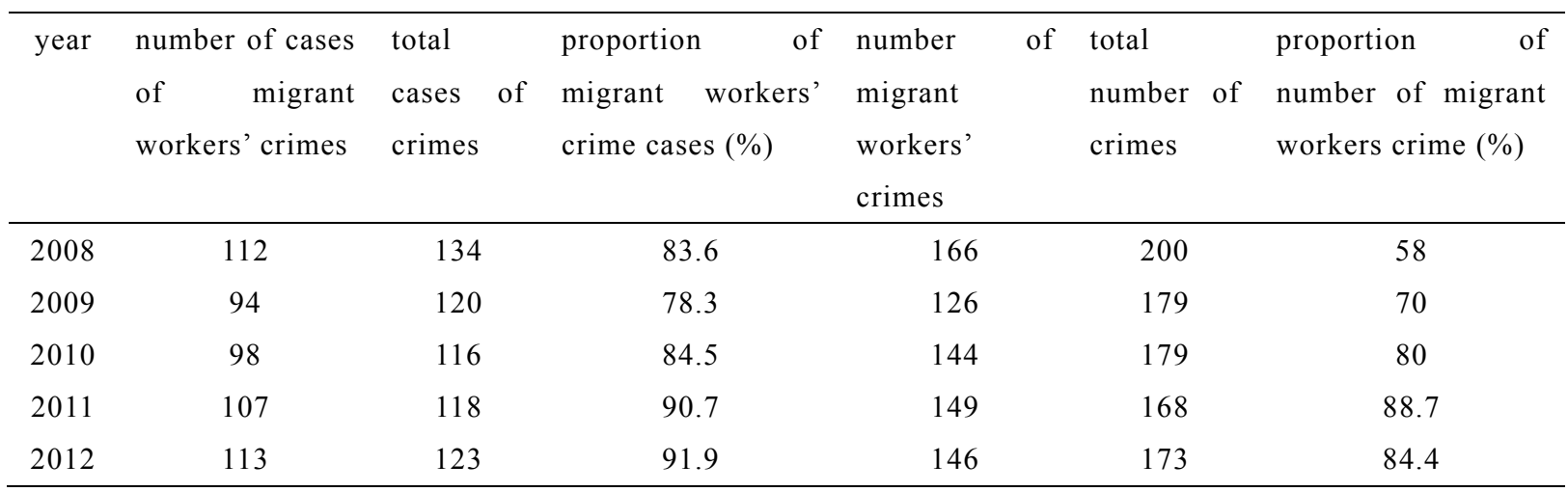

Statistics from Linyi Procuratorate, Linyi, Shandong

The increasingly serious crimes of migrant workers do great damage to social order, and become an important factor of affecting social stability. The rational understanding of this social phenomenon, and analysis of its individual and social causes, are of positive significance for effective control and prevention of this kind of crimes.

\section{Characteristics of the Migrant Workers' Crimes}

Through the study on the characteristics of migrant workers' crimes, we can be more clear to understand why they gradually fall into the abyss of crime. The characteristics of their crimes can be reflected by the subject characteristics and type characteristics.

\subsection{Subject Characteristics of Migrant Workers' Crimes}

3.1.1 The Migrant Worker Criminals Tend to Be Younger, and the New Generation Constitutes a Large Proportion

Many criminals are $19-25$ years old, accounting for $46 \%$ of the total population of floating population, criminals aged 26-35 coming next (36.3\%), then under 18 (9.1\%), While the vast majority of the floating population are constituted by migrant workers. From the view of intergenerational Differences, the first generation of migrant workers accounted for $13 \%$, the new generation $87 \%$. The new generation of migrant workers has become the main force of these criminals. From the structure of population, many criminals of new generation are left unattended children or migrant children. In recent years, more and more minors become migrant worker, and the criminals tend to be younger.

This characteristic can be interpreted as, increase in labor demand with the enlargement of the scale of the construction of city caused by the overall improvement of the social economy and civilization level. Young migrant workers comply with the expanding need. On the other hand, the young migrant workers are psychologically immature, and are more vulnerable to the adverse effects of the environment, which may lead to crimes. 


\subsubsection{Migrant Worker Criminals Were Dominated by Males}

Take statistics from Linyi Procuratorate as an example, in the past five years, male migrant workers accounted for $67 \%$, female ones for $33 \%$. According to the investigation and statistics on crimes of migrant workers, male criminals accounted for around $90 \%$, female ones for only about $10 \%$.

Table 2.

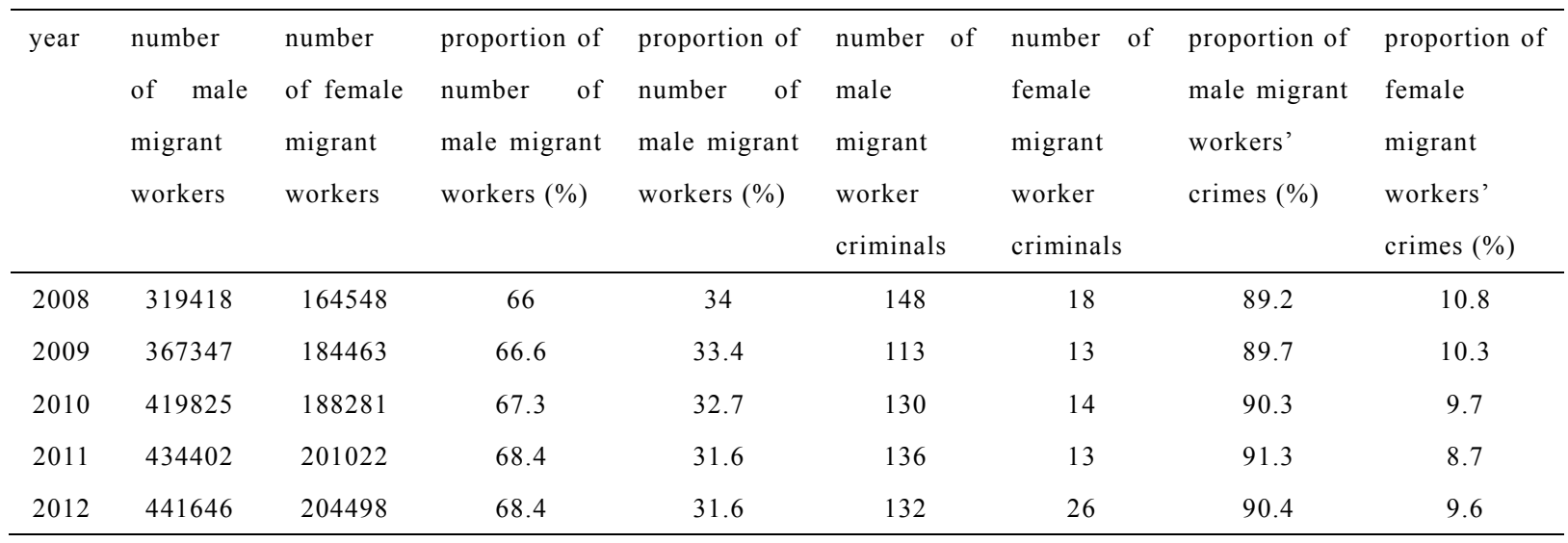

Statistics from Linyi Procuratorate, Linyi, Shandong

Obviously, male migrant workers are the mainstream of crimes. In addition, males commit various crimes, and means and methods of crimes are more complicated. By contrast, the type and means of female crimes are relatively simple, mainly about the crimes against personal rights and sex crimes. Thus, punishment applied to male criminals should be paid much attention to, and women criminals be well guided.

In fact, a high proportion of male criminal is common. The area of activity is relatively large for males, and they have higher economic independence because of cultural tradition, which, to a certain extent, contribute to more possibility to commit crimes. This point is related to the characteristic that most crimes are against property discussed later.

\subsubsection{Migrant Workers Are Generally Poorly Educated and Very Weak in the Understanding of Law}

According to our survey, the level of education of migrant workers is mainly junior middle school. The illiterate migrant workers accounted for $1.5 \%$, workers with the educational level of at primary school $14.4 \%$, junior middle school for $61.1 \%$, senior middle school $13.2 \%$, technological secondary school and higher ones only $9.8 \%$. It's clear that the migrant workers are poorly educated. The criminal investigation on migrant workers revealed that the levels of education of these criminals were mainly elementary and junior middle schools, with a small proportion of criminals from senior middle school or higher ones and vocational colleges which foster thetechnical personnel. Thus, it can be safely concluded that education on migrant workers has a significant impact on crime rates, and the lower level of education they receive, the more likely they commit crimes by comparing the statistics. In addition, according to the questionnaires on criminals, the vast majority of them had never received formal legal education. Most were lack of legal awareness, and even some of them were not clear whether their actions had violated the law. It is a very serious problem, and a weak legal awareness has become a potential threat to the social development.

\subsubsection{Migrant Worker Criminals Are Mainly Service Workers or Engaged in Unstable Occupations}

The basic assumption is that, the service industry or occupation is not stable, which will pose a threat to the basic living conditions of migrant workers.

Migrant worker criminals are mainly form the service industries. In 115 subjects, 60 were engaged in relatively stable occupations when they commit crimes, while 55 were unemployed or not engaged in stable occupations. Among the 60 subjects, 21 were working in lodging or catering industries (35\%), 16 in resident services or other services $(26.67 \%)$, with a total of 37 people $(61.67 \%)$. In addition, there are 12 engaged in transportation industry $(20 \%) ; 5$ in the building industry $(8.33 \%) ; 4$ in manufacturing industry $(6.67 \%)$; and 2 in wholesale and retail trade $(3.33 \%)$.

According to China's "Monitoring Survey on Migrant Workers in 2012", migrant workers were still engaged in 
the manufacturing, construction and service industries. The share of migrant workers in the manufacturing amounted to the most part $(36.0 \%)$, followed by workers in building industry $(17.7 \%)$, resident services and other services $(12.2 \%)$, wholesale and retail trade $(10.1 \%)$, transportation, warehousing and postal services (6.6\%), lodging and catering industries (5.3\%). Thus, most migrant workers are in the service industry, and because of the openness of their workplaces and occupations, crimes are apt to be perpetrated.

Through the previous analysis, we can come to the preliminary judgement that younger age, males dominated, low education level and being engaged in instable service industry are the subject characteristics of migrant workers' crimes. Thus it can be seen that blindness and low economic status easily lead to their rush into danger, which is an important factor to induce crimes.

\subsection{Type Characteristics of Migrant Workers' Crimes}

Investigation into migrant workers crime types can help us to correctly understand the social and individual reasons why migrant workers commit crimes. The following investigation and analysis will illustrate.

1) Mostly crimes are against property with lower values of the crime subjects. From the types, crimes were highly concentrated on to those against property. Finance is usually the biggest problem for migrant workers. Making money to survive takes precedence of other purposes. Migrant workers usually commit crimes to accrue economic benefits, manifested in theft, robbery, forcible seizure and others. According to the survey, $78.4 \%$ of the crimes committed by them were crimes against property, in which theft accounted for $62.6 \%$, robbery $13.3 \%$, and fraud 2.5\%. And this characteristic had much to do with their unstable occupations and lower incomes. Based on the questionnaire on these criminals, $89.3 \%$ commit crimes because they had lost the least source of income, when some were unemployed or jobless for a long time, when the bosses refused to pay or defaulted wages, when some had too much work for too little pay, when some were ill or disabled in the course of their employment but could not get proper medical treatment allowance, or when their income was inadequate to meet the expense.

2) Violence is a prominent characteristic. The escalating violence is a primary characteristic of crimes committed by migrant workers, especially the new generation. In a survey, violent crimes kept some growth in the stability from 2005 to 2012, with the largest proportion in intentional injury, followed by robbery, intentional homicide and others. In recent years, the new generation joined in migrant workers were young, loyal to their friends but in utter disregard of the consequences, therefore they became the subjects of violent crimes, more than $90 \%$ violent crimes committed by them. Violent crimes rose continuously and major crimes increased enormously, illustrating a new trend of the new generation of migrant workers.

In the urban luxury and dissipation, migrant workers often achieve their goals of consuming, possessing or venting resentment through robbery, forcible seizure and injury.

3) Organized crimes are common. Migrant Workers, affected by rural traditional culture, have strong sense of geographic kinship. They tend to collude with fellow villagers, classmates, and/or friends to form loosely-or-well-organized criminal gangs, such as theft gangs, robbery gangs, drug manufacturing and dealing gangs and organized prostitution gangs. In all types of criminal gangs, more than $70 \%$ were organized by classmates, relatives and friends, owning to affinity of geopolitical kinship and same experiences. Sense of similarity makes them easy to understand each other and become partners to form relatively close criminal gangs. According to statistics from a five-year survey (2008-2012) in a prison, organized crime has become a major mode of migrant workers' crime. And organized criminal gangs are newly characteristic of formation turning mainly from fellow villagers to friends gradually, showing the trend that migrant workers are breaking the traditional geopolitical kinship because of close social interaction and openness. Furthermore, with the expansion of the migrant workers' interpersonal communication in floating, interpersonal resources and the possibility of organization of criminal gangs also increased. You can found gang crimes obviously tend to ascent. As vulnerable groups in society, migrant workers are difficult to seek a place in this world alone, therefore they prefer to rely on the power of the "organization" to be strong, doing greater harm to the society.

4) Localities of the crimes have regular patterns. Localities of the crimes committed by migrant workers are mainly in the streets and lanes, rental estates, hotels and internet bars. The victims are not only the natives but also the other migrant workers. According to statistics, $31 \%$ of crimes occurred in the streets and lanes, $19 \%$ in hotels, $14 \%$ in the rental estates, and $9 \%$ in the internet bars. And the localities are closely related to the age and gender, males tending to commit crimes in the streets, lanes and internet bars, while females in hotels and rental estates, where are all favorable sites to commit crimes. Characteristics of migrant workers crime localities can clearly illustrate that migrant workers' crimes are committed mainly under economic pressure of life, and the lack of sufficient and thorough plan. 
5) Crimes committed by self-help are obvious. Migrant workers' crimes committed by self-help occur when they defend their rights or interests by means of crimes on condition that their survival and development are threatened or legal interests are violated. These crimes are committed mostly in the following circumstances: 1) Migrant workers who were not paid demanded the salary from the boss together with a bunch of his fellow villagers. They were more likely to vandalize and fight when rejected. Severe cases might be crimes against public and private property, crimes of affray and intentional assaults. 2) Some migrant workers who were not paid would steal the products, raw materials, components or tools to sell for "self-fulfilling", committing the crime of theft. This is why these migrant workers often just steal from the unit they were working for but not others. 3) They might resort to violence to revenge the unpaid bosses and their families directly. Severe cases might be crimes of intentional homicide, intentional injuries, robbery, kidnapping and other serious ones.

According to the questionnaire, $20 \%$ migrant workers' crimes are those committed by self-help, among which violent crimes account for $14 \%$, and non-violent ones $7 \%$. From the large proportion of violent crime's we can see that they were vindictive when they commit this type of crime.

With the analysis of type characteristics, we can see clearly that crimes against property, violence, organized crimes and self-help are the basic characteristics of migrant workers' crimes. Thus it can be seen that the demand for economic interests and the violence of rush into danger are important factors to induce migrant workers' crimes. There is a close relationship between the general subject characteristics and type characteristics of their crimes. In a word, it is likely to be the low economic status of migrant workers -- because of the unfair social distribution or limited individual survival ability, and the cognitive ability limited by the low education level with their psychological imbalance lead to their crimes.

\section{Analysis of the Causes of the Migrant Workers' Crimes}

The type and means of migrant workers' crime are diverse, and causes of crime are much more complex. The problem of migrant workers' crimes does not appear suddenly, but has deep social origins. It involves conflicts between social classes and deficiencies in the system acting on migrant workers. Many people put all the blame on migrant workers' poor qualities, however, we should also find out the unfavorable factors: social injustice, imperfect social system, violation or inadequate protection of rights and interests of migrant workers. We think, the crime is a product of alienation of social environment and defects of individual characteristics, Therefore this paper will illustrate both the social factors and individual factors induced migrant workers' crime and their criminal psychology.

\subsection{Social Factors}

\subsubsection{Urban-Rural Dual System Is the Origin of Migrant Workers' Crimes}

This system is a major obstacle for economic and social development in China, mainly manifested by household registration between urban and rural areas, two different resource allocation system, and other problems based on household registration. The city's migrant workers are the result of the dual household registration system. We can say that without household registration system, there would be no concept of "migrant workers", let alone the problem of migrant workers' crimes. Dual social structures resulted in the unequal status of urban and rural residents, wide income inequality and uneven social security, which led to resentment and psychological imbalance of migrant workers, and propelled some towards a life of crime.

The present urban-rural dual system proscribes migrant workers from sharing national resources with urban residents. Various systems attached to the household registration system adversely affectes migrant workers' life and work in the city. The employment system, education system, personnel system, and social security system pose direct obstacles to them. Policy and system adopt double standards for urban and rural residents, protecting the former, while limiting the latter.

Specifically, It can be concluded that the following incentives are mainly caused by the urban-rural dual system: 1) Status discrimination prevents migrant workers from integrating into urban society. In dual household registration system, even the geographical restrictions can be broken, they can not break through the identity limits, neither can they share national treatment with urban residents. As "outsiders", they are ostracized and discriminated by urban residents, which hurt their personality and dignity badly. They cannot build trust on urban residents or integrate into mainstream, which make them drift away city society to be marginal groups on the bottom of rung. 2) Restrictions in employment and unfair working conditions. "From the current situation of China, for both the urban poor group and migrant workers, they have one thing in common to commit crimes, that is, they are living in extreme poverty." Most migrant workers aim to find a good job in the city to pursue benefits, however, they are restricted in choosing occupations, types of job and posts. They can not compete with 
urban residents at the same level due to the policies in cities, their own cultural qualities, and invariable discrimination from the urban residents. Most of them are engaged in work which are dirty, dangerous, exhausting, hard and under atrocious conditions with lower payment. And they are often treated unjustly. Some of them may be desperate to commit crimes to realize their "urban dreams". 3) Lack of social security. The present social security system proscribes migrant workers from sharing the same treatment on education, medical care and other securities. Their children have difficulty in attending school, and they have to afford high school-choosing fee. The urban medical security system can only provide protection for the urban residents, but give no guarantee to the migrant workers. Migrant Workers are a group of people without "security". it's very difficult for them to find a system to rely on to survive in the city. Being away from home and without any social securities, they are prone to resist the society by committing crimes if they are unemployed without income, they cannot afford to treat illness, and they cannot get compensation after industrial injury.

\subsubsection{Unreasonable Social Management System Is the Result of Migrant Workers' Crimes}

Nowadays, it is observed that the urban management system for migrants basically is still in the framework of planned economy, and based on crime prevention as a starting point. Migrant Workers are still being treated unfairly. As Zhao Shukai said, "Now the main deficiency of urban public management for migrant workers, is that prevention and constraint are emphasized but the service is absent. Irregular management or even the irrational management policy design is often an important factor in inducing misconducts of the foreign population."

The deficiencies of current management system in China mainly include: 1) Dislocation of management concept. The government regards the management as the means of controlling migration and preventing crimes, but ignores the service it should provide. In the management process, the emphasis is on cracking down and preventing migrant workers' crimes, and some discriminatory policies were developed, which, in a manner, contributed to the city's discrimination against migrant workers. Crimes are apt to be induced on condition that the government ignores the rights and interests of migrant workers, and their needs cannot be satisfied. 2) Shifting of dual system. The urban-rural dual system itself is the origin of migrant workers' crimes. However, the city managers do not try to dodge or attenuate this problem. The separate management of the urban residents and the migrant workers, in fact, change the spatially divided urban-rural social management into inner-city social management, which strengthens but not weaken the dual system in the social life of the city. 3) Irregularities of the administrators and their behaviors. There are no specialized agencies to manage migrant workers, Migrant Workers have to be governed by multiple departments concerned to survive in the city. Actually, the specified powers and responsibilities in administration for migrant workers performed by these departments are not clear, thus there is even the problem of subject legality of them. Lack of a unified management system makes certificate transaction for migrant workers in disorder. Also, some managers' misconducts lead to new conflicts and even the local management crisis. Therefore this management situation, to some extent, intensify social conflicts, and bring out the crimes.

We can draw the conclusion that the unreasonable social management system is the institutional reason for migrant workers' crimes.

4.1.3 Legal Rights and Interests of Migrant Workers Cannot Be Guaranteed, Which Is the Fuse Leading to Migrant Workers' Crimes

Living in cities, migrant workers often stay in passive and dangerous situation, the behavior against their legal rights and interests frequently occur. The employers often deduct and delay the payment or even refuse to pay. With the increase in the number of migrant workers, the job market is tough, and it is a "buyer's market", in which those representing capital or the employers are in a dominant position. In addition, the faulty security mechanism for their legal rights and interests and the corresponding remedies available deteriorate the living conditions of migrant workers. The migrant worker are prone to commit crimes when they cannot making a living.

Moreover, migrant workers are also victims whose legal rights and interests are often violated. It is difficult for them to find a stable living environment and to protect their legal rights and interests through legal means. Judicial authorities impose simple and crude management and even discriminate migrant workers in dealing with criminal acts, reducing migrant workers' desire to seek help, or increasing their distrust and even hostility toward the public service departments and the society. Defects in legal system foreshadow the crimes the migrant workers may commit. Furthermore, migrant workers are away from the constraints from the rural society, family and moral, and the flippancy of the city, diversity of crime objects, adequate criminal conditions and and other factors, undoubtedly, provide opportunities to commit crimes. 
In short, the difference between urban and rural areas, oppressive management and right discrimination are the social factors for migrant workers to the road of crime.

\subsection{Individual Factors}

The strange environment, poor economy, low educational level, mental depression are the individual reasons for migrant workers' crimes.

\subsubsection{Poor Adaptability Living in Cities}

A person is likely to be irritable when there is strong inadaptability, and the possibility of offense is also increased. From rural to urban areas, migrant workers do not just transfer spatially, or change in environment and living styles but also integrate into the new urban social environment and apply urban values and behavior patterns. Such changes force the migrant workers adapt themselves in economic life, social communication and values to the new urban communities. Before coming into a city, migrant workers had been living in rural communities which are significantly differently from urban communities, and they were accustomed to simple, close and equal relationship among people. They had to change their opinions and lifestyles to face the complex urban environment and fast-paced lifestyle after coming into a city. So there exist problems of one kind or another during the process of their adaptation.

\subsubsection{Poor Economic and Living Conditions}

Migrant workers belong to groups with low incomes, they shoulder huge survival and developmental stresses. Among migrant workers' criminals, only a few have great income, more than $70 \%$ have no income or just get to make ends meet, Many migrant workers are in the status of high labor intensity, low income and inadequate rest before committing a crime. Living a happy and prosperous life is both a beautiful illusion and a haunting shadow. In order to seek a better life, some people had to increase their incomes by committing crimes. It is very difficult for them to survive in the world.

Migrant workers are wanting in spiritual life. They spend their leisure time surfing the internet, playing cards, drinking or chatting. Being lack of positive life and cultural universes, they have no spiritual life pursuit. And violent online games, pornography and places for entertainment are easy to induce crimes.

\subsubsection{Poor Level of Education and Personal Quality}

Level of education is one of the signs of a person's socialization. Though the educational level cannot entirely determine a person's psychological development and patterns of behavior, lack of knowledge or means of living is bound to hinder his/her socialization. Generally speaking, migrant workers have lower educational level, and they don't have the same living standards and opportunities as the urban residents to be educated and trained. Therefore, academic qualifications and other obstacles often keep the migrant workers out of the job market. In addition, when they are in trouble, many migrant workers don't analyze the situation and find a reasonable solution, but often rush off on individual impulse and make decisions arbitrarily.

\subsubsection{Imbalanced Mental Health Condition}

As a vulnerable group, many migrant workers live in poverty, which determines their lower life of quality as well as lower ability to bear anything happening. The psychological imbalance of migrant workers is mainly characterized by the following: 1) Psychological sense of being discriminated. Migrant Workers suffer from unfair treatment in the city, management policies and the citizens take a distorted view on them. Migrant Workers can not enjoy the preferential policies of the city, but are restricted in all respects and discriminated as the city's lowest stratum, In such condition, migrant workers would be self-abased and resentful. Such emotional surge will lead to hatred and antagonism toward the society. which further contribute to crimes. 2) Relative sense of being stripped. Relative sense of being stripped is a psychological imbalance generated from the huge gap between what a person actually gets and what he expects, and between what one get and what they others get. On the one hand, migrant workers come to the city with a dream and hope, expecting to have a happy life.

However, the city is not as good as they have expected. Mostly migrant workers have no fixed residence or occupation, and live in poverty, which brings them with great psychological blow and sense of being stripped from the city. On the other hand, migrant workers and urban workers can not share equal pay for equal work, as well as the social welfare and subsidies. The social security is just urban privilege. Under the same condition, the urban residents get more than migrant workers. Migrant Workers deeply felt great difference and social inequality, which lead to their general hostility and resistance toward the city and urban residents.

\section{A Brief Discussion and Conclusion}

From the above study and analysis we can see, migrant workers' crime has become a serious problem in current 
Chinese society. Migrant workers crime reflects the defects of social reform in the course of industrialization and urbanization in china. The defects of the social system demonstrate the differences between urban and rural areas, oppressive management and rights discrimination, which lead to migrant workers' tragic fate, and shape their personality abnormality. The two aspects eventually contribute to the severe situation of migrant workers' crime. We intend to relate the situation with sociological and psychological theories.

Maslow's "hierarchy of needs theory" provides persuasive psychological explaination for migrant workers' crimes. According to this theory, people's needs are in five levels: physiological needs, safety needs, love and belonging, esteem and self-actualization. When these needs cannot be fulfilled through the normal channels, they may be solved by means of the crime. Due to various reasons, migrant workers are often out of work, even lead a vagrant life. Sense of security can not be guaranteed. They lack of access to trust, friendship, care, emotional social opportunity. Esteem need is trampled. They are unable to use their own potential to realize their ideals and ambitions. When they can not be satisfied by reasonable means, some migrant workers will be propelled towards a life of crime. "High proportion of migrant workers in cities have ever been penniless, being excluded from the city's security system, breaking the law or rules becomes a survival means for some people."

According to American sociologist Merton's "social anomie" theory, culture leads to purposes, and social structure determines means to achieve these goals. If you accept the achievement goal advocated by the society, but lack of legal means, the results would be anomie and various forms of deviant behaviors. Based on the theory, migrant workers may use social disapproval means, or even illegal means because they lack legal means to achieve economic success after they come into the city. Compared with them, it's relatively much easier for city residents to get access to economic opportunities and institutional means. It can be predicted that with the process of urbanization in China, if the social system and social structure do not change, migrant workers' crime proportion will be higher and higher. In addition, because the main target for migrant workers' coming into city is to make money, it can be asserted that the main type of migrant workers crime is the crime against property. The investigation results of crimes against property above proved this theory.

On the other hand, American sociologist Merton earlier proposed the theory of "reference group". According to it, when individuals compare their own situation with the reference group of people and find themselves at a disadvantage, they will feel that they have been deprived of some kind of rights. In China, the migrant workers 'deprivation is universal, and it is institutional. The most obvious difference is the household registration. The migrant workers and city residents belong to two completely different household register systems, so migrant workers are in the position or state of deprivation in all household-related interests,. As for employment, in very long period of time, many city labor departments have strict limits on industry and occupation for extraneous people. As for wages, there generally exists the phenomenon of unequal pay for equal work between migrant workers and city residents. There were also significant differences in education, health care, housing, security between the two groups. Deprivation may partly explain the following three phenomena: first, why the crimes intensively occur in the city? Second, why the crime population mostly float from rural to city? Third, why the crime against property in floating crime population is so outstanding?

Therefore, to control the crime of migrant workers' crime radically, the long-term social reform is essential. In promoting the reform of industrialization and urbanization, we should pay more attention to migrant workers, who make up of a large social vulnerable group. And we should strive to improve the welfare of them, maintain the basic rights of their survival and development, and shape fair and just social systems. 1) Set up a fair social security system. It can ensure the migrant workers to enjoy the same treatment as the city resident employers. Only in this way can we truly make the migrant workers integrate into the city life. 2) Improve the standards of service for the migrant workers. The government should take various measures to improve the standards of service for the migrant workers, and try to solve all kinds of problems, such as residence, livelihood, their children's education, to provide security for their normal work and life. 3) Strengthen legal education, vocational and technical education. Local government could conduct adult colleges or evening classes for the migrant workers to help them better understand the basic situation and abide by the law. At the same time, we can organize publicity activities in the communities inhabited by migrant workers at regular or irregular intervals, to improve their legal and comprehensive qualities. 4) Improve the migrant workers' cultural life. Migrant workers are completely strange to city life, thus social life space for migrant workers is in a closed state. In an unfamiliar environment, self control ability and moral norms binding force are reduced, it will be easy to be misled. The government should strengthen the construction of public cultural and recreational facilities of the communities inhabited by migrant worker, carry out rich and colorful social activities to improve their cultural life, strengthen the connection between the urban inhabitants and the migrant workers. 5) The reform of the household registration system is essential. The ultimate goal of the reform of the household registration system is the 
elimination of identity difference between farmers and city residents to unify into the category of citizens of the People's Republic of china. But at present the feasible approach might be to patch up the differences between them. Some requirements can be set up to allow migrant workers to become urban inhabitants, such as the relatively stable jobs and income in the city, living in the city over a certain period.

\section{References}

Fan, P. (1996). Low-income people in urban China: Sociological investigation on the poor urban employers. Chinese Social Sciences, (4).

Garida, H. K. S. (2009). Analysis and Inspiration of the Concept of the Western Social Integration. Western Social Science, (2).

Li, Q. (2002). The city of migrant workers and the city informal employment in the. Sociological research, (6).

Maslow, A. H. (1943). A theory of human motivation. Psychological Review, 50(4), 370-396. Retrieved from $\mathrm{http}: / /$ psychclassics.yorku.ca/Maslow/motivation.htm http://dx.doi.org/10.1037/h0054346

Merton, R. K. (1968). Social Theory and Social Structure. New York, Free Press.

National Bureau of Statistics of PRC. (2012, February 22). National Economic and Social Development Statistics Bulletin of PRC2011. Retrieved from http://www.stats.gov.cn

Phillips, E. (1990). Criminal sociology (Translated by Guo Jianan). Chinese People's Public Security University Press.

Wang, C. L. (2002). Analysis of Migrant workers' crimes committed by self-help. Wuhan Public Security College.

Zhao, S. K. (2005). Misconducts and Public Management: A Case Study on the rural population working in cities. Beijing: Rural Economic Research Department of the Development Research Center of the State Task Force.

Zhu, L. (2000). Quasi-identity in public. Journal of Nanjing University (Philosophy and Social Science), 6(4).

Zhu, L. (2002). On adaptation of migrant workers in cities. Jianghai Academic Journal, (6).

\section{Copyrights}

Copyright for this article is retained by the author(s), with first publication rights granted to the journal.

This is an open-access article distributed under the terms and conditions of the Creative Commons Attribution license (http://creativecommons.org/licenses/by/3.0/). 